\title{
PENGARUH ION LOGAM Cd(II) TERHADAP EKSTRAKSI ION TIMBAL(II) MENGGUNAKANTEKNIK EMULSI MEMBRAN CAIR
}

\author{
Effect of Cd(II) Metal Ion towards Extraction of Lead(II) Ion using Liquid \\ Emulsion Membrane Technique
}

\begin{abstract}
*Rizka Setyani, Baharuddin Hamzah, dan Suherman
Pendidikan Kimia/FKIP - Universitas Tadulako, Palu - Indonesia 94118

Received 16 March 2016, Revised 18 April 2016, Accepted 17 May 2016

Abstract

This study aims to study on the effect the addition of Cd(II) metal ions towards extraction of lead (II) ions using liquid emulsion membrane technique. Various concentrations of Cd(II) ions usedin this study were 0 ppm, 50 ppm, 100 ppm, 150 ppm, 200 ppm, and 250 ppm. Benzoyl acetone was used as a chelating agent for extraction. Spectrophotometer Spectrodirect was used to measure extraction products.. The results showed that percent extraction of lead (II) ion prior additional Cd(II) ion was $99.06 \%$, and it was decreased up to $97.95 \%$ after additional Cd(II) ion up to $250 \mathrm{ppm}$.
\end{abstract}

Keywords: Extraction, liquid emulsion membrane, cadmium(II) ion, lead(II) ion, benzoyl acetone

\section{Pendahuluan}

Logam berat merupakan unsur alami dari kerak bumi dengan memiliki sifat yang stabil, tidak bisa rusak atau hancur, sehingga cenderung menumpuk dalam tanah dan sedimen (Khofsoh \& Rachmadianti, 2012). Salah satu contohnya seperti keberadaan ion logam berat pada limbah cair industri pada pelapisan logam, industri baterai, industri cat dan industri keramik. Akibat dari sifat-sifat logam berat yang beracun, sehingga dapat menyebabkan dampak pencemaran lingkungan dan akhirnya dapat mengganggu kesehatan bagi makhluk hidup seperti timbul berbagai penyakit yaitu penyakit kanker, paru-paru, hepatitis, anemia, diare, dan lain-lain (Hamzah dkk., 2011).

Logam timbal murni di bumi jumlahnya hanya sedikit, yaitu $0,0002 \%$ dari jumlah unsur penyusun kerak bumi bila dibandingkan dengan jumlah kandungan unsur lainnya yang ada di bumi (Widowati dkk., 2008). Logam timbal mudah melarut dalam asam nitrat yang sedang pekatnya $(8 \mathrm{M})$, sehingga terbentuk nitrogen oksida seperti reaksi berikut (Svehla, 1990):

$3 \mathrm{~Pb}+8 \mathrm{HNO}_{3} \rightarrow 3 \mathrm{~Pb}^{2+}+6 \mathrm{NO}_{3}^{-}+2 \mathrm{NO}+4 \mathrm{H}_{2} \mathrm{O}$

*Correspondence:

Rizka Setyani

Program Studi Pendidikan Kimia, Fakultas Keguruan dan

Ilmu Pendidikan, Universitas Tadulako

email: setyani.rizka@yahoo.com

Published by Universitas Tadulako 2016
Kadmium (Cd) merupakan logam berat yang berwarna putih perak, lunak, mengkilap, tidak larut dalam basa, mudah bereaksi, serta menghasilkan kadmium oksida bila dipanaskan. Kadmium melarut dengan lambat dalam asam encer dengan melepaskan hidrogen (disebabkan elektrodenya yang negatif). Kadmium membentuk ion bivalen yang tak berwarna (Svehla, 1990). Adapun reaksinya sebagai berikut:

\section{$\mathrm{Cd}+2 \mathrm{H}^{+} \rightarrow \mathrm{Cd}^{2+}+\mathrm{H}_{2}$}

Membran cair adalah fasa yang bersifat pemisah semipermeabel (tidak semua zat dengan ukuran tertentu yang dapat larut) yang berada diantara dua fasa cair lain yang sejenis. Membran cair tidak bisa larut dalam kedua fasa yang dipisahkannya. Emulsi membran cair terdiri dari tiga tahap utama yaitu; fasa internal, fasa eksternal dan fasa membran. Fase membran dalam tahap ini dibuat dengan melarutkan Span-80 sebagai surfaktan (Ahmad dkk., 2012). Kedua fasa yang dibatasi oleh membran masing-masing disebut fasa eksternal dan fasa internal. Fasa eksternal berisi senyawa-senyawa yang akan dipisahkan (ekstraktan) terlarut. Fasa internal merupakan fasa penerima senyawasenyawa yang telah dipisahkan dari fasa eksternal melalui fasa membran ke fasa internal (Purwani \& Biyantoro, 2013). Sistem membran cair emulsi dibentuk dengan pembuatan emulsi terlebih dahulu. Ukuran butiran emulsi 
tergantung pada sifat dan konsentrasi surfaktan dalam emulsinya, viskositas, cara dan intensitas pengadukan serta waktu pembuatan emulsi. Surfaktan pada membran cair emulsi berfungsi sebagai zat penstabil emulsi/emulgator (Setiarso \& Purwanti, 2006).

Keselektifan membran cair terhadap komponen yang akan ditranspor dapat diperoleh dengan penambahan zat pembawa sebagai mediator dan pengaturan kondisi operasi yang tepat saat pemakaian membran sehingga tidak terjadi reaksi balik (Tetra, 2010). Ekstraksi logam dengan teknik membran cair selalu dibutuhkan zat pembawa (ekstraktan). Ekstraktan yang sering digunakan yaitu benzoil aseton (Hamzah dkk., 2013).

Proses membran cair surfaktan memiliki kemampuan yang cukup untuk selektif logam terpisah dari air solusi menggunakan ganda W/O/W emulsi distabilkan oleh penggunaan surfaktan yang cocok, dengan mengurangi jumlah pelarut organik dan ekstraksi lebih besar (Basualto dkk., 2009). Penggunaan membran cair diperlukan adanya larutan yang bertindak sebagai emulsi. Emulsi ada 2 yaitu tipe O/W artinya Oleum dalam Water atau minyak dalam air atau sebaliknya air dalam minyak (W/O). Dalam menjaga kestabilan emulsi selama proses ekstraksi, emulsi yang digunakan harus fasa membran yang tidak larut dalam fasa eksternal, sehingga fasa eksternal yang digunakan air sebagai pelarut maka jenis emulsinya adalah W/O atau air dalam minyak (Hamzah dkk., 2013).

Menurut Khaoya \& Pancharoen, (2012) untuk membran cair didukung dengan ekstraktan organik. Membran cair emulsi dalam membran ini, fase organik dibuat dengan menggunakan pengencer, pembawa dan emulsifier/fase surfaktan organik yang dicampur dengan larutan untuk membentuk emulsi dan emulsi dikocok bersama dengan fasa eksternal. Setelah pengocokan, campuran dipisahkan menggunakan corong pisah. Stabilitas membran adalah faktor utama untuk menentukan proses pemisahan. Stabilitas emulsi ditentukan oleh pembentukan monolayer oleh surfaktan antara minyak dan tahapan air (Manikandan dkk., 2014).

Teknik emulsi membran cair memiliki mekanisme transfer massa sebanyak tiga jenis yaitu difusi, difusi yang diikuti dengan reaksi fasa internal dan difusi dengan reaksi dalam membran. Mekanisme transfer massa dalam penelitian ini menggunakan difusi dengan reaksi kimia dalam fasa membran. Mekanisme transfer massa ini didasarkan pada reaksi antara ion logam misalnya $\mathrm{M}^{2+}$ dengan pereaksi $2 \mathrm{HR}$ (zat pembawa) yang dilarutkan dalam membran. Tulisan ini bertujuan untuk untuk melihat dan mempelajari pengaruh ion kadmium(II) terhadap persen ekstraksi ion timbal(II) menggunakan teknik emulsi membran cair. Mekanisme transfer massa ini dapat dilihat pada Gambar 1:

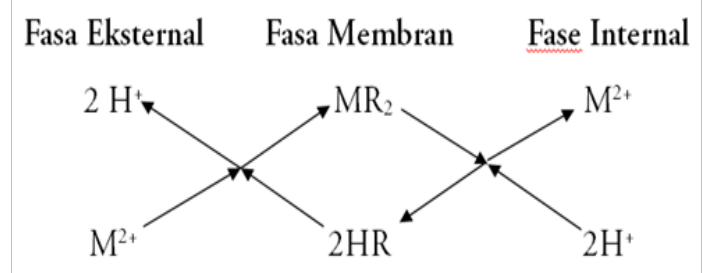

Gambar 1. Mekanisme Transfer Massa melalui Difusi dengan Reaksi Kimia dalam Fasa Membran (Hamzah dkk., 2011)

\section{Metode}

Bahan-bahan yang digunakan pada penelitian ini yaitu benzoil aseton (Merck), SPAN-80, paraffin cair, $\mathrm{HNO}_{3}$ (Smart-Lab indonesia), $\mathrm{Pb}\left(\mathrm{NO}_{3}\right)_{2}$ (Aldrich), aquades, dan $\mathrm{Cd}(\mathrm{NO})_{3}$ (Merck). Sedangkan alat yang digunakan pada penelitian ini yaitu spektrofotometer spektrodirect (Lovibond), gelas kimia, gelas ukur, labu ukur, neraca analitik, spatula, batang pengaduk, magnetic strirer, pipet tetes, pipet volume, karet penghisap, statif dan klem, corong pisah, Cimarec Stiring dan Hot Plates.

\section{Prosedur Kerja \\ Pembuatan Larutan Pb(II) dengan Konsentrasi 500 ppm dalam $1000 \mathrm{~mL}$}

Timbal(II) nitrat ditimbang sebanyak 0,7995 gram dilarutkan di dalam gelas kimia. Kemudian larutan tersebut diencerkan ke dalam gelas ukur $1000 \mathrm{~mL}$ dengan menggunakan aquades hingga mencapai tanda batas dan ditambahkan 3 tetes larutan $\mathrm{HNO}_{3}$ 0,01 M.

Proses Ekstraksi dengan Teknik Emulsi Membran Cair

1) Emulsi dibuat dengan cara diaduk dan dicampurkan dengan fasa membran (benzoil aseton 0,02 M, parafin cair dan span-80 3\%) dengan fasa internal yang mengandung larutan HNO3 3 M (diaduk dengan skala 10 selama 10 menit). Perbandingan volume fasa membran $12 \mathrm{~mL}$ dan fasa internal $18 \mathrm{~mL}$ yaitu 2:3.

2) Dicampurkan $90 \mathrm{~mL}$ larutan ion $\mathrm{Pb}(\mathrm{II})$ dengan konsentrasi 500 ppm pada ( $\mathrm{pH} \mathrm{2)}$ dan $90 \mathrm{~mL}$ larutan ion Cd(II) dengan variasi 
konsentrasi yaitu 0 ppm, 100 ppm, 200 ppm, 300 ppm, 400 ppm, dan 500 ppm. Kemudian dilakukan proses ekstraksi dengan kecepatan pengadukkan pada skala 5 selama 15 menit. Setelah itu, hasil ekstraksi dipisahkan antara fasa eksternal dengan emulsi dengan menggunakan corong pemisah. Sisa ion timbal(II) yang masih berada dalam fasa eksternal diukur dengan menggunakan Spectrofotometer Spectrodirect.

Mengetahui besar persen ekstraksi ion timbal(II) yang berhasil terekstrak ke dalam fasa membran (parafin cair), maka dilakukan pengukuran terhadap banyaknya ion timbal(II) yang masih tersisa dalam fasa eksternal. Pengukuran ini menggunakan alat Spectrofotometer Spectrodirect. Untuk mengetahui besarnya persen ekstraksi ion timbal(II) yang diperoleh pada penelitian ini digunakan persamaan sebagai berikut (Chang dkk., 2010):

$$
\% \mathrm{E}=\frac{[\mathrm{Pb}]_{\text {awal }}-[\mathrm{Pb}]_{\text {akhir }}}{[\mathrm{Pb}]_{\text {awal }}} \times 100 \%
$$

dimana, $\% \mathrm{E}=$ persen ekstraksi ; $[\mathrm{Pb}]$ awal= konsentrasi awal ion timbal(II) dalam larutan (fasa eksternal) ; $[\mathrm{Pb}]$ akhir $=$ konsentrasi akhir ion timbal(II) dalam larutan (fasa eksternal) setelah ekstraksi.

\section{Hasil dan Pembahasan}

Berdasarkan penelitian yang telah dilakukan maka diperoleh data hasil analisis pengaruh penambahan logam $\mathrm{Cd}(\mathrm{II})$ terhadap persen ekstraksi ion timbal(II) seperti pada Tabel 1 .

Tabel 1. Hasil Analisis Pengaruh Penambahan Logam Cd(II) terhadap Persen Ekstraksi Ion

$$
\text { Timbal(II) }
$$

\begin{tabular}{|c|c|c|c|c|c|c|c|}
\hline \multirow{2}{*}{ No } & \multirow{2}{*}{$\begin{array}{c}\text { Konsentrasi } \\
\text { Cd(II) yang } \\
\text { ditambahkan } \\
\text { (ppm) }\end{array}$} & \multirow{2}{*}{$\begin{array}{c}\text { Konsentrasi } \\
\mathrm{Pb} \text { awal } \\
(\mathrm{ppm})\end{array}$} & \multicolumn{4}{|c|}{$\begin{array}{l}\text { Konsentrasi } \mathrm{Pb} \text { setelah } \\
\text { ekstraksi }(\mathrm{ppm})\end{array}$} & \multirow{2}{*}{$\begin{array}{c}\% \\
\text { Ekstraks } \\
\mathrm{Pb}\end{array}$} \\
\hline & & & I & II & III & $\begin{array}{c}\text { Rata- } \\
\text { rata }\end{array}$ & \\
\hline 1. & 0 & 245 & 2,33 & 2,28 & 2,29 & 2,3 & 99,06 \\
\hline 2. & 50 & 245 & 5,05 & 5,01 & 4,95 & 5 & 97,95 \\
\hline 3. & 100 & 245 & 5,81 & 5,88 & 5,85 & 5,85 & 97,61 \\
\hline 4. & 150 & 245 & 5,57 & 5,51 & 5,55 & 5,54 & 98,14 \\
\hline 5. & 200 & 245 & 4,18 & 4,24 & 4,14 & 4,2 & 98,28 \\
\hline 6. & 250 & 245 & 4,92 & 5,04 & 4,9 & 4,95 & 97,97 \\
\hline
\end{tabular}

Berdasarkan data pada Tabel 1. dapat dilihat bahwa sebelum dilakukan penambahan logam Cd(II) diperoleh persen ekstraksi dari ion timbal(II) adalah 99,06\%. Namun, setelah dilakukan penambahan logam $\mathrm{Cd}(\mathrm{II})$ dengan konsentrasi $50 \mathrm{ppm}$ persen ekstraksi ion timbal(II) mengalami penurunan yaitu menjadi $97,95 \%$ seperti yang terlihat pada Gambar 2.

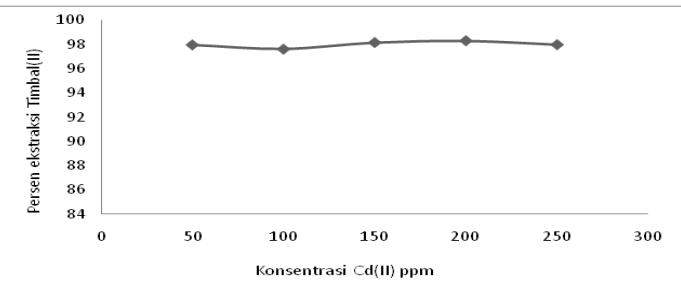

Gambar 2. Grafik pengaruh penambahan logam $\mathrm{Cd}(\mathrm{II})$ terhadap persen ekstraksi ion timbal(II)

Faktor yang dapat mempengaruhi keberadaan logam $\mathrm{Cd}(\mathrm{II})$ yaitu peningkatan $\mathrm{pH}$ larutan fasa eksternal, konsentrasi surfaktan, dan konsentrasi asam internal. Menurut Masgul, (2014), bahwa pada + pH 2 merupakan kondisi optimum dari persen ekstraksi timbal(II) dengan menggunakan teknik emulsi membran cair. Berdasarkan hasil tersebut sehingga dalam penelitian ini menggunakan kondisi $+\mathrm{pH}$ 2. Namun, pada $\mathrm{pH} 2$ tersebut bukanlah $\mathrm{pH}$ ekstraksi dari logam Cd(II). Menurut Alif dkk, (2005) bahwa $\mathrm{pH}$ ekstraksi dari ion $\mathrm{Cd}(\mathrm{II})$ berada pada $\mathrm{pH} 6,0-10,2$. Sehingga ion $\mathrm{Cd}(\mathrm{II})$ tidak begitu mempengaruhi hasil ekstraksi dari ion timbal(II) tersebut.

Pengaruh konsentrasi surfaktan yang digunakan juga merupakan salah satu faktor terhadap hasil persen ekstraksi yang diperoleh, dimana surfaktan yang digunakan dalam penelitian ini adalah Span-80 dengan konsentrasi 3\%. Penggunaan surfaktan tersebut didasarkan pada peneliti sebelumnya oleh Masgul, (2014) menyatakan bahwa surfaktan dengan konsentrasi 3\% merupakan kondisi optimum dari hasil persen ekstraksi timbal(II). Sehingga apabila pada konsentasi tersebut ion Cd(II) tidak begitu berpengaruh terhadap hasil persen ekstaksi timbal(II). Selain itu, pemilihan suatu surfaktan juga berdasarkan dari nilai HLB agar diperoleh emulsi yang stabil. Dalam penelitian ini juga menggunakan parafin cair yang memiliki nilai HLB 4 untuk tipe $\mathrm{W} / \mathrm{O}$, sehingga surfaktan yang digunakan harus memiliki nilai HLB 4 atau mendekati 4. Span-80 yang digunakan dalam penelitian ini adalah surfaktan anionik yang berupa cairan bewarna kuning dengan rumus $\mathrm{C} 22 \mathrm{H} 44 \mathrm{O}$, berat molekul $428 \mathrm{~g} / \mathrm{mol}, \mathrm{HLB}=4,3$ (Setiarso \& Purwanti, 2006).

Menurut Hamzah, (2010) dalam penelitiannya menggunakan kerosen yang memiliki nilai HLB 6,0 untuk emulsi tipe W/O 
dan di dalam kerosen tersebut mengandung surfaktan campuran antara Span-80 dan Span20 dengan perbandingan yang proporsional pada konsentrasi 2\%. Konsentrasi suatu surfaktan juga mempengaruhi kekentalan emulsi, dimana kekentalan ini berpengaruh terhadap efesiensi pemisahan pada proses emulsi. Berdasarkan proses tersebut maka dapat digambarkan mekanisme transfer massa melalui difusi dengan reaksi kimia dalam fasa membran seperti pada Gambar 3.

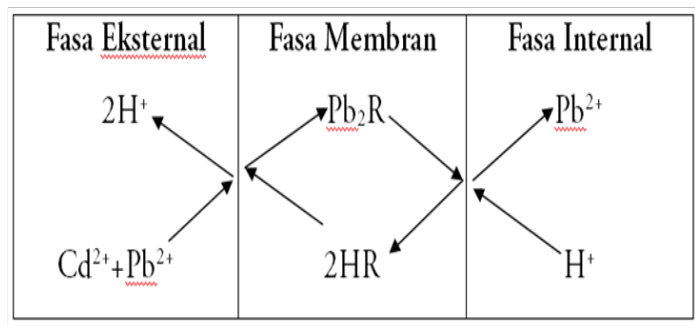

Gambar 3. Membran Mekanisme Transfer Massa melalui Difusi dengan Reaksi Kimia dalam Fasa Membran (Hamzah, 2010)

Berdasarkan Gambar 3, dapat dijelaskan bahwa logam Cd(II) dan timbal(II) awalnya bersama-sama dalam fasa eksternal namun ketika akan berdifusi menuju ke fasa membran logam Cd(II) hanya terekstraksi sebagian hal ini dikarenakan membran yang digunakan dalam proses ini tidak sesuai dengan logam Cd(II), dimana khelat tersebut lebih sedikit yang mengikat ion $\mathrm{Cd}(\mathrm{II})$ dibandingkan pada saat mengikat ion $\mathrm{Pb}(\mathrm{II})$. Sehingga ion $\mathrm{Cd}(\mathrm{II})$ tidak dapat menuju ke fasa internal.

Ikatan kimia yang terjadi antara gugus aktif pada bahan organik dengan logam dapat dianalogkan sebagai perilaku interaksi asam basa lewis yang menghasilkan kompleks pada permukaan padatan. Dimana bagian aktif pada permukaan padatan dapat dianggap sebagai ligan yang dapat mengikat logam secara selektif. Logam dan ligan dikelompokan menurut sifat keras dan lunaknya berdasarkan pada kepolaran unsur. Suatu prinsip yang disebut Hard and Soft Acid Bases (HSAB), dimana ligan-ligan dengan atom yang sangat elektronegatif dan berukuran kecil merupakan basa keras, sedangkan liganligan dengan atom yang elektron terluarnya mudah terpolarisasi akibat pengaruh ion dari luar, merupakan basa lunak. Ion-ion logam yang berukuran kecil namun bermuatan positif besar, elektron terluarnya tidak mudah terpengaruh oleh ion dari luar, ini dikelompokkan ke dalam asam keras, sedangkan ion-ion logam yang berukuran besar dan bermuatan kecil atau nol, elektron terluarnya mudah terpengaruh oleh ion lain, maka dikelompokan ke dalam asam lunak.

Asam keras akan berinteraksi dengan basa keras untuk membentuk kompleks, begitu juga asam lunak dengan basa lunak. Interaksi asam keras merupakan interaksi ionik, sedangkan interaksi asam lunak dengan basa lunak, interaksinya lebih bersifat kovalen. Ion $\mathrm{Pb}(\mathrm{II})$ berada pada golongan asam peralihan sehingga cenderung lebih tertarik pada ligannya yaitu benzoil aseton, sedangkan ion Cd(II) cenderung tidak tertarik oleh ligan karena berada pada golongan asam lunak. Proses pembentukan kompleks yang terjadi antara ion $\mathrm{Pb}$ (II) dengan ligan benzoil aseton, pada permukaan luar membran melibatkan pertukaran dua buah hidrogen dengan sebuah ion Timbal(II). Kompleks terbentuk diawali dengan reaksi antara ion timbal(II) yang berada dalam fasa eksternal dengan benzoil aseton yang berada dalam fasa membran, dimana reaksi tersebut terjadi dipermukaan luar membran. Kompleks yang terbentuk kemudian akan berdifusi ke permukaan dalam membran. Di permukaan dalam membran ion $\mathrm{Pb}^{2+}$ akan dilepaskan ke dalam fasa internal karena $\mathrm{HNO}_{3}$ dalam fasa internal yang berfungsi sebagai stripping agent. Kemudian benzoil aseton yang terbentuk kembali dalam fasa membran akan terdifusi kembali ke permukaan luar membran untuk membentuk kompleks yang baru (Prayitno \& Budiyono, 2001).

Penelitian ini menggunakan asam $\mathrm{HNO}_{3}$ dengan konsentrasi $3 \mathrm{M}$, penggunaan tersebut didasarkan pada peneliti sebelumnya oleh Astuti, (2014) menyatakan bahwa hasil persen ekstraksi ion timbal (II) optimum diperoleh pada konsentrasi tersebut. Sedangkan menurut Hamzah, (2010) dalam penelitiannya menggunakan konsentrasi asam adalah 1\%. Sehingga apabila menggunakan konsentrasi asam yang lebih tinggi akan lebih cepat memutuskan ikatan kelat pada suatu logam. Namun, hal ini tidak berpengaruh terhadap penambahan logam $\mathrm{Cd}(\mathrm{II})$ karena pada konsentrasi tersebut merupakan kondisi optimum dari persen ekstrasi $\mathrm{Pb}(\mathrm{II})$.

Kestabilan emulsi juga merupakan salah satu faktor keberhasilan proses ekstraksi dengan teknik emulsi membran cair. Emulsi yang dibuat dalam proses ektraksi harus dalam keadaan sestabil mungkin sehingga dapat mengekstraksi logam yang diinginkan. Kestabilan suatu emulsi dipengaruhi oleh beberapa keadaan yaitu fasa membran (jenis, konsentrasi dan volume), fasa internal, dan fasa eksternal ((Handini dkk., 2011). Dalam proses pembuatan emulsi 
dibutuhkan laju emulsifikasi, sehingga dalam penelitian ini menggunakan laju emulsifikasi dengan skala 10 dengan menggunakan Cimerec Stirring and Hot selama +10 menit. Waktu emulsifikasi yang digunakan dalam penelitian ini didasarkan peneliti sebelumnya yaitu oleh Hamzah, (2010) yang menyatakan bahwa pada lama waktu tersebut memperoleh hasil yang emulsi yang stabil. Selain itu, menurut Prayitno \& Sardjono, (2000) menyatakan bahwa pengaruh waktu ekstrasi terhadap penurunan konsentrasi terjadi karena membran akan menarik umpan atau logam dari fasa internal yang ada di sekelilingnya ke dalam fasa membran, di mana semakin lama waktu ekstraksi maka akan semakin baik karena pengikatan membran terhadap logam akan semakin kuat pula.

Menurut Prayitno \& Budiyono, (2001) bahwa kecepatan pengadukan emulsi mempengaruhi ukuran partikel emulsi yang akan dihasilkan, jika kecepatan pengadukan rendah, maka ukuran partikel emulsi yang sangat kecil belum terbentuk sempurna sehingga daya pisahnya rendah. Sedangkan apabila kecepatan pengadukannya terlalu tinggi, emulsi akan pecah. Selain itu, waktu pengadukan emulsi berpengaruh juga terhadap ukuran partikel dalam emulsi. Dengan bertambahnya waktu pengadukan partikel yang terbentuk semakin banyak. Hal ini menyebabkan tumbukan semakin sering, dan pada akhirnya terjadi koalesen (penyatuan tetes kecil menjadi besar dan akhirnya menjadi fasa tunggal yang memisah) sehingga emulsi tidak stabil. Penelitian Span - 80 pada sistem emulsi berfungsi sebagai penurun tegangan antarmuka, span - 80 akan mengatur dirinya dalam posisi bagian yang lipofil(bersifat minyak) dalam fase minyak dan bagian hidrofil pada fase air. Penggunaan span - 80 yang kurang akan menyebabkan pembentukan lapisan tipis monomolekuker tidak tersusun rapat sehingga membran emulsi tidak stabil.

Penelitian ini digunakan konsentrasi Cd(II) dengan berbagai variasi konsentrasi yang bertujuan untuk melihat pengaruh konsentrasi Cd(II) tersebut terhadap hasil persen ekstraksi ion timbal(II). Berdasarkan hasil yang diperoleh seperti pada Tabel 1, bahwa hasil persen ekstraksi ion timbal(II) yang diperoleh secara relatif tidak berubah berdasarkan variasi konsentrasi tersebut. Namun, pada proses ekstraksi tersebut melainkan hanya ion timbal(II) yang terekstraksi lebih banyak dibandingkan dengan ion Cd(II). Dengan kata lain bahwa ion Cd(II) tidak ikut terekstraksi ke fasa membran. Hal ini dikarenakan pada proses ini menggunakan kondisi optimum dari ion timbal(II). Proses ekstraksi ion timbal(II) dengan teknik emulsi membran cair terjadi karena pada proses tersebut, dimana ion timbal(II) yang awalnya berada dalam fasa eksternal dan kemudian akan terekstrak ke dalam fasa internal dengan bantuan dari ekstraktan yang terdapat dalam fasa organik (Prayitno \& Budiyono, 2001)

Menurut Prayitno \& Budiyono, (2001) bahwa transfer tembaga dari fase air eksternal menuju bidang antar muka fase air eksternal dengan fase membran terjadi setelah membran emulsi cair terdispersi dalam fase air ekternal akibat pengadukan yang dilakukan. Dimana kompleks tembaga dengan ekstraktan terjadi pada bidang antar muka fase air eksternal dengan fase membran. Selanjutnya kompleks tersebut kemudian melewati fase membran menuju fase internal. Difusi kompleks tembaga ekstraktan melalui fase membran menuju bidang antar muka fase membran dengan fase air internal terjadi karena adanya gradien konsentrasi ion $\mathrm{H}+$ antara fase air eksternal dengan fase air internal. Pada bidang antar muka fase membran dengan fase air internal terjadi dekomposisi kompleks tembaga ekstraktan dimana terjadi proses penukaran ion hidrogen pada fase air internal dengan ion tembaga. Ekstraktan menangkap ion hidrogen yang dilepaskan dari fase internal membran dan terdifusi balik ke dalam membran menuju bidang antar muka fase membran dengan fase air eksternal untuk mengekstrak tembaga kembali.

\section{Kesimpulan}

Keberadaan ion $\mathrm{Cd}(\mathrm{II})$ relatif tidak berpengaruh terhadap hasil persen ekstraksi ion timbal(II) karena setelah dilakukan penambahan logam $\mathrm{Cd}$ (II) dengan konsentrasi hingga $250 \mathrm{ppm}$ persen ekstraksi ion timbal(II) mengalami penurunan menjadi $97,95 \%$.

\section{Ucapan Terima Kasih}

PenulismengucapkanterimakasihkepadaIda Kesuma Utami selaku pengelola Laboratorium Agroteknologi Fakultas Pertanian Universitas Tadulako yang telah banyak membantu penulis dalam menyelesaikan penelitian ini.

\section{Referensi}

Ahmad, A. L., Buddin, M. M. H. S., \& Kusumastuti, B. S. O. A. (2012). Cadmium removal using vegetable oil based emulsion liquid membrane (ELM): membrane breakage investigation. Jurnal Teknologi, 75(1), 39-46. 
Alif, A., Noritatetra, O., Aziz, H., \& Emriadi. (2005). Pengaruh ion Cd(II) dan Fe(III) terhadap transpor $\mathrm{Cu}(\mathrm{II})$ melalui meknik emulsi cair fasa ruah. Jurnal Kimia Andalas, 11(1), 6-9.

Astuti, W. (2014). Variasi perbandingan volume fasa membran dan fasa internal serta konsentrasi $\mathrm{HNO}_{3}$ dalam fasa internal terhadap ekstraksi ion timbal(II) menggunakan teknik emulsi membran cair. Skripsi Program Studi Pendidikan Kimia Jurusan Pendidikan MIPA Fakultas Keguruan dan Ilmu Pendidikan Palu: Universitas Tadulako. Tidak diterbitkan.

Basualto, C., Poblete, M., Marchese, J., Ochoa, A., Acosta, A., Sapaga, J., \& Valenzuela, F. (2009). Extraction of cadmium from aqueous solutions by emulsion liquid membranes using a stirred transfer cell contactor. Laboratorio de Operaciones Unitarias, Facultad de Ciencias Químicas y Farmacéuticas, Universidad de Chile, Casilla 233, Vicuña Mackenna 20, Santiago, Chile, 1347 - 1354.

Chang, S. H., Teng, T. T., \& Ismail, N. (2010). Optimization of $\mathrm{Cu}$ (II) extraction from aqueous solution by soybean-oil-based organic solvent using response surface methodology. Journal Water, Air and Soil Pollution, 217, 567-576.

Hamzah, B. (2010). Aplikasi 1-fenil-3-metil-4benzoil-5-pirazolon sebagai pembawa kation pada ekstraksi ion tembaga(II) menggunakan teknik emulsi membran cair., Disertasi Doktor Kimia pada Universitas Hasanuddin Makassar, Tidak Diterbitkan.

Hamzah, B., Jalaluddin, N., Wahab, A. W., \& Upe, A. (2011). Pengaruh kadmium(II) dan nikel(II) pada ekstraksi ion tembaga(II) dengan ekstraktan 4-benzoil-1-fenil-3metil-2-pirazolin-5-on menggunakan emulsi membran cair Jurnal Natural Indonesia, 13(3), 269-275.

Hamzah, B., Pulukadang, S. H. V., \& Hardani, R. (2013). Sintesis ekstraktan turunan pirazolon dan uji kestabilan emulsi untuk ekstraksi ion raksa(II) menggunakan teknik emulsi membran cair. Prosiding Seminar Nasional Sains dan Matematika Jurusan Pendidikan MIPA FKIP, Palu : Universitas Tadulako
Handini, T., Bambang, \& Purwoto. (2011). Menentukan konstante kecepatan reaksi pada ekstraksi zirkonium-hafnium dengan metoda membran cair. Prosiding seminar penelitian pengelolaan perangkat nuklir, ISSN 1410-8178. Yogyakarta: Pusat Teknologi dan Proses Bahan.

Khaoya, S., \& Pancharoen, U. (2012). Removal of lead(II) from battery industry wastewater by HFSLM. International Journal of Chemical Engineering and Applications, 3(2), 98-103.

Khofsoh, A., \& Rachmadianti, D. A. (2012). Analisis logam kadmium (Cd). Diunduh Kembali dari http://viidislamlovers.files. wordpress.com

Manikandan, G. N., Bogeshwaran, K., Jamuna, P., \& Sandhya, S. (2014). A review on emulsion liquid membranes on heavy metal separation. International Journal of ChemTech Research CODEN (USA): IJCRGG, 6(9), 4329 - 4332.

Masgul, S. D. (2014). Variasi konsentrasi span80 dan $p H$ fasa eksternal pada ekstraksi ion timbal(II) dengan metode emulsi membran cair. Skripsi Program Studi Pendidikan Kimia Jurusan Pendidikan MIPA Fakultas Keguruan dan Ilmu Pendidikan, Palu: Universitas Tadulako Tidak diterbitkan.

Prayitno, \& Budiyono, M. E. (2001). Penurunan kadar tembaga dalam air limbah dengan proses ekstraksi membran cair. Prosiding Pertemuan dan Presentasi Ilmiah Penelitian Dasar Ilmu Pengetahuan dan Teknologi Nuklir Yogyakarta: P3TMBATAN

Prayitno, \& Sardjono, D. (2000). Penurunan kadar merkuri pada limbah cair dengan teknik membran emulsi cair. Prosiding Presentasi Ilmiah Keselamatan Radiasi dan Lingkungan, Yogyakarta: Puslitbang Teknologi Maju BATAN.

Purwani, M., \& Biyantoro, D. (2013). Ekstraksi pemisahan Th-Ce dari Ce hidroksida hasil olah monasit menggunakan membran emulsi cair dengan solven TBP. Journal Teknologi Bahan Nuklir, 9(2), 55-113.

Setiarso, P., \& Purwanti, N. S. (2006). Ekstraksi ion logam nikel(II) dan tembaga(II) menggunakan teknik membran cair emulsi. 
Indonesia Journal Chemistry, 6(2), 186-188. melalui teknik membran cair fasa ruah.

Svehla, G. (1990). Analisis anorganik kualitatif makro dan semimikro Jakarta: Penerbit Kalman Media Pusaka.

Tetra, O. N. (2010). Transpor antar fasa $Z n(I I)$
Diseminarkan pada seminar dan rapat tahunan BKS-PTN Indonesia Bagian Barat Bidang MIPA, Pekan Baru, 1-9.

Widowati, W., Sastiono, A., \& Jusuf, R. R. (2008). Efek toksik logam. Yogyakarta: Andi. 